\title{
Prevalence of QTc interval prolongation and its associated risk factors among psychiatric patients: a prospective observational study
}

\author{
Zahid Ali ${ }^{1}$ (D) Mohammad Ismail ${ }^{*}$ (D), Zahid Nazar ${ }^{2}$, Fahadullah Khan ${ }^{1}$, Qasim Khan $^{3}$ and Sidra Noor ${ }^{1}$
}

\begin{abstract}
Background: QT interval prolongation is a growing concern worldwide, posing psychiatric patients to lifethreatening fatal arrhythmias i.e., torsade de pointes. This study aimed to identify the prevalence of QT interval prolongation, its associated risk factors and prescribing patterns of QT prolonging drugs among psychiatric patients.

Method: A prospective observational study was conducted that included psychiatric patients from a tertiary care hospital and a psychiatry clinic in Peshawar, Khyber Pakhtunkhwa, Pakistan. Electrocardiogram was recorded of those patients who were using psychotropic medications for $\geq 7$ days, aged 18 years or more, and of either gender, male or female. The Fredericia correction formula was used for measuring QTc values (corrected QT). Chi-square test was applied to estimate differences between patients with or without prolonged QTc interval whereas, logistic regression analysis was performed to identify various predictors of QT interval prolongation.

Results: Out of 405 patients, the QTc interval was prolonged in 23 (5.7\%) patients including 1 (0.2\%) patient with highly abnormal prolonged QTc interval (> $500 \mathrm{~ms})$. QT drugs (91.6\%), female sex (38.7\%) and hypertension (10.6\%) were the most common QT prolonging risk factors. Prolonged QTc interval was significantly higher among male patients $(p=0.007)$.

Conclusion: In the present study, QT interval prolongation was observed in a considerable number of psychiatric patients. While, the high prevalence of QT prolonging risk factors among these patients warrants the increased risk of fatal arrhythmias. Therefore, risk assessment and electrocardiographic monitoring, and prescription of safer alternatives are highly recommended.
\end{abstract}

Keywords: QT interval prolongation, Prevalence, Risk factors, Torsade de pointes, Psychotropics, Psychiatry

\section{Background}

QT interval prolongation (QTIP) is a well-known surrogate marker for torsades de pointes (TdP), a lifethreatening ventricular arrhythmia, that may result in sudden cardiac death [1-4]. QTIP is a consequence of

\footnotetext{
*Correspondence: ismailrph@uop.edu.pk

'Department of Pharmacy, University of Peshawar, Peshawar, Khyber Pakhtunkhwa, Pakistan

Full list of author information is available at the end of the article
}

abnormality in the ion channels of the heart such as potassium, sodium, and calcium channels [5]. Cardiac channel abnormalities may be congenital or acquired, the latter is more common and is often associated with drugs [6].

Psychiatric patients are at higher risk of drug induced $\mathrm{TdP}$ because majority of the psychotropic agents (antipsychotics and antidepressants) are notorious for prolonging the QT interval [7]. The risk is further

C C The Author(s). 2020 Open Access This article is licensed under a Creative Commons Attribution 4.0 International License, which permits use, sharing, adaptation, distribution and reproduction in any medium or format, as long as you give appropriate credit to the original author(s) and the source, provide a link to the Creative Commons licence, and indicate if changes were made. The images or other third party material in this article are included in the article's Creative Commons licence, unless indicated otherwise in a credit line to the material. If material is not included in the article's Creative Commons licence and your intended use is not permitted by statutory regulation or exceeds the permitted use, you will need to obtain permission directly from the copyright holder. To view a copy of this licence, visit http://creativecommons.org/licenses/by/4.0/ The Creative Commons Public Domain Dedication waiver (http://creativecommons.org/publicdomain/zero/1.0/) applies to the data made available in this article, unless otherwise stated in a credit line to the data. 
enhanced in patients with other QT prolonging risk factors such as bradycardia, diabetes mellitus, hypertension, advance age, female sex, underlying heart diseases and illicit drugs use [8-10].

Psychiatric patients are often exposed to psychotropic polypharmacy [11, 12], high dose therapy and illicit drug use, which considerably increase the probability of exposure to QT prolonging drugs and QT drug-drug interactions (QT-DDIs) [10, 13]. In psychiatry settings, polypharmacy is a traditional and old practice that is increasingly becoming a norm rather than exception. In a review on polypharmacy in psychiatry, Kukreja et al. reported the prevalence of psychiatric polypharmacy ( $\geq 2$ drugs) between 13 and $90 \%$ [14]. Another study reported, 19\% prevalence of multi-class psychotropic polypharmacy among children and adolescents [15]. According to a study, since 1974 prescriptions containing $\geq 3$ drugs increased from $5 \%$ to $40 \%$ in 1995 [16].

In addition, among psychiatric patients, the higher risk of QTIP is also due to frequent QT prolonging antidepressant and antipsychotic combinations [4, 17]. In most clinical conditions, $>1$ psychotropic drug is indicated $[18,19]$. In some clinical situations, compared to a single antidepressant or antipsychotic drug, patients with psychiatric illnesses significantly improved after adding a second psychotropic drug in the prescription [20-23]. However, another study also reported significant increase in psychotropic polypharmacy in a psychiatry setting with many combinations of unproven efficacy that are not supported by controlled clinical trials [11]. Recently, a study reported higher prevalence of contraindicated combinations with two antidepressants (escitalopram or citalopram) among hospitalized patients [24]. Using $>1$ QT prolonging medications simultaneously increase the risk of life-threatening ventricular arrhythmias [25].

Psychiatric polypharmacy, psychotropic QT prolonging drug combinations and high dose therapies are inevitable in such a population due to multiple illnesses and tolerance to the recommended dose of therapy $[13,26$, 27]. The increased prevalence of polypharmacy, contraindicated combinations and high dose therapy coupled with poor access to health care facilities increase the risk of QTIP associated morbidity and mortality [14, 24, 28].

Despite considerable safety concern for QTIP associated with psychotropic drugs, studies are scarce regarding the prevalence of QTIP and its associated risk factors among psychiatric patients, particularly in the developing countries. Moreover, electrocardiographic monitoring for QTIP is not performed in routine clinical practice despite the known risk of QTIP and TdP with psychotropic agents $[9,29]$. Therefore, this study aimed to identify the prevalence of QTIP, its associated risk factors and prescribing patterns of QT prolonging drugs in psychiatric patients.

\section{Methods \\ Design and settings}

A prospective observational study was conducted at the psychiatry ward of a tertiary care hospital and a psychiatry clinic of a provincial capital. The convenience sampling technique was used to include patients diagnosed with psychiatric diseases, who used psychotropic medications for $\geq 7$ days, aged 18 years or more (adult), and of either gender, male or female from January 31, 2018 till July 30, 2018. The Institutional Review Board (IRB) of the hospital granted the ethical approval for this study. Prior to participation, a written consent was obtained from all patients.

\section{Data collection and analysis}

Patient's relevant data required for this study was obtained from the medical profile of individual patient. After recording ECG the following data were collected from the patient's medical record; gender, age, main diagnosis, comorbidities other than psychiatric disorders (if any), and prescribed medications.

The corrected QT interval (QTc) was manually calculated from the patient's ECG using the Fredericia $(\mathrm{QTcF})$ [30], and Bazett's (QTcB) correction formula (QTcB results only presented in supplementary Table S1) [31]. QT interval was measured from the start of QRS complex till the end of T wave from lead- II on the surface of ECG. The QTIP was defined as, QTc values above $450 \mathrm{~ms}$ and $470 \mathrm{~ms}$ for male and female patients, respectively [32]. Whereas, values above $500 \mathrm{~ms}$ were considered highly abnormal irrespective of gender [33]. CredibleMeds database was used for the identification of QT prolonging drugs and their TdP risk categories [7]. Whereas, Micromedex DrugReax ${ }^{\circ}$ database was used for the identification of QT-DDIs [34].

\section{Statistical analysis}

For categorical variables, chi-square test was applied to identify the differences for various variables between patients with or without QTIP. Logistic regression analysis was performed to calculate the odds ratios for various predictors of QTIP. A $p$-value of 0.05 or less was considered statistically significant. SPSS version-23 was used for statistical analysis.

\section{Results}

This study included 405 psychiatric patients, of which 61.2\% ( $n=248)$ were males and $38.8 \%$ (157) were females. The mean age of patients was $34.6 \pm 13.8$ years while ranging from 18 to 80 years. Majority of patients were prescribed $2-3$ drugs (63\%), followed by $25.2 \%$ 
patients who were using $>3$ drugs concomitantly. Of the total patients, major depression $(52.1 \%)$ was the most frequent diagnosis followed by manic depressive psychosis $(8.9 \%)$, panic disorder (8.4\%) and psychosis (7.7\%). Whereas, hypertension (10.6\%) and diabetes mellitus (4.2\%) were the most common co-morbidities (Table 1).

Of total 405 patients, 23 (5.7\%) patients were found to have prolonged QTc interval, while only one patient (0.2\%) had highly abnormal QTc interval (> $500 \mathrm{~ms})$, and $12.3 \%$ of patients had QTc value in the borderline range. Moreover, with QTcB, we noted higher prevalence of QTIP (27.2\%) than QTcF (5.7\%), details of which are provided in supplementary Table S1. QTIP was significantly higher among male patients $(p=0.03)$. Whereas, no statistically significant differences were observed between the two groups i.e., patients with QTIP vs. patients with normal QT interval with respect to other clinical characteristics (Table 2). All patients (100\%) with prolonged QT interval were exposed to one or more QT

Table 1 General characteristics of patients

\begin{tabular}{|c|c|}
\hline Variables & $\boldsymbol{n}(\%)^{a}$ \\
\hline \multicolumn{2}{|l|}{ Gender } \\
\hline Male & $248(61.2)$ \\
\hline Female & $157(38.8)$ \\
\hline \multicolumn{2}{|l|}{ Age (years) } \\
\hline$\leq 20$ & $81(20)$ \\
\hline $21-30$ & $109(26.9)$ \\
\hline $31-40$ & $98(24.2)$ \\
\hline$>40$ & $117(28.9)$ \\
\hline \multicolumn{2}{|l|}{ All prescribed drugs } \\
\hline 1 & $48(11.9)$ \\
\hline $2-3$ & $255(63)$ \\
\hline$>3$ & $102(25.2)$ \\
\hline \multicolumn{2}{|l|}{ Diagnosis } \\
\hline Major depression & $211(52.1)$ \\
\hline Manic depressive psychosis & $36(8.9)$ \\
\hline Panic disorder & $34(8.4)$ \\
\hline Psychosis & $31(7.7)$ \\
\hline Obsessive compulsive disorder & $18(4.4)$ \\
\hline Schizophrenia & $17(4.2)$ \\
\hline Hypomania & $13(3.2)$ \\
\hline Bipolar affective disorder & $11(2.7)$ \\
\hline Substance abuse & $17(4.2)$ \\
\hline \multicolumn{2}{|l|}{ Co-morbid illnesses } \\
\hline Hypertension & $43(10.6)$ \\
\hline Diabetes mellitus & $17(4.2)$ \\
\hline Epilepsy & $13(3.2)$ \\
\hline
\end{tabular}

${ }^{a}$ Percentage calculated in total of 405 patients prolonging drugs. At least one QT-DDI was present in 9 (39.9\%) patients with QTIP.

Table 3 shows frequencies of QT prolonging drugs and their therapeutic classes along with their TdP risk among patients with QTIP. All patients with prolonged QTc interval $(n=23)$ were receiving QT prolonging drugs. Of which, the most frequently prescribed drug classes were antidepressants $(n=13)$, and antipsychotics $(n=5)$. Among antidepressants, $30.4 \%$ of the drugs were carrying conditional risk of $\mathrm{TdP}$, and $17.4 \%$ were having known risk of TdP. Among antipsychotics, $8.6 \%$ of the drugs were having known and possible risk of TdP, respectively. Moreover, majority of the patients (65.2\%) with QTIP had no QT prolonging risk factors except exposure to QT prolonging drugs and female gender, indicating the high probability of drug induced QTc interval prolongation, details have been presented in supplementary Table S2.

Univariate, and multivariate logistic regression analysis demonstrated significant association of QTIP with male gender ( $p=0.03$ and $p=0.007$, respectively) as compared with females as shown in Table 4. No statistical association was observed with other clinical characteristics (Table 4).

\section{Discussion}

This present study found QTIP in 5.7\% of the patients that is higher in comparison to studies conducted in developed countries [35-40]. The study also identified highly abnormal QTIP $(>500 \mathrm{~ms}$ ) in $0.2 \%$ of patients which is lower than studies conducted in Japan (1.2 and 3\%) [41, 42], Italy (2.3\%) [9], Spain (2\%) [43], and Switzerland (0.9\%) [39]. These inconsistencies in prevalence rates may be attributed to variability in the study population and drug prescribing/utilization patterns among respective countries. On the contrary, we observed higher prevalence of QTIP with QTcB, details of which are presented in supplementary Table S1 because majority of studies conducted in psychiatry settings have used QTcB [9, 39, 41-43]. Therefore, health care professionals should be more vigilant regarding the assessment and prevention of QTIP among psychiatric patients.

The risk of QTIP was 5.6 times higher in males than in female patients, which is in contrast with the findings of other studies [44, 45]. However, some studies have reported mixed results regarding the prevalence of QTIP with respect to gender $[46,47]$. This high prevalence of QTIP in males may be attributed to high frequency of prescribed QT prolonging drugs. In the present study, no statistically significant association of QTIP were observed with age, multiple drugs, $\geq 2$ QT prolonging drugs, medical and co- 
Table 2 Comparative analysis of patients with normal and prolonged QTc interval

\begin{tabular}{|c|c|c|c|}
\hline \multirow[t]{2}{*}{ Variables } & \multicolumn{2}{|l|}{ QTc interval } & \multirow[t]{2}{*}{$p$-valu } \\
\hline & $\begin{array}{l}\text { Normal } \\
(\boldsymbol{N}=382)^{a} \\
\boldsymbol{n}(\%)\end{array}$ & $\begin{array}{l}\text { Prolonged } \\
(\boldsymbol{N}=23) \\
\boldsymbol{n}(\%)\end{array}$ & \\
\hline \multicolumn{4}{|l|}{ Gender } \\
\hline Male & $229(92.3)$ & $19(7.7)$ & \multirow[t]{2}{*}{0.03} \\
\hline Female & $153(97.5)$ & $4(2.5)$ & \\
\hline \multicolumn{4}{|l|}{ Age (years) } \\
\hline$\leq 20$ & 75 (19.6) & $6(26.1)$ & \multirow[t]{4}{*}{0.45} \\
\hline $21-30$ & $105(27.5)$ & $4(17.4)$ & \\
\hline $31-40$ & $94(24.6)$ & $4(17.4)$ & \\
\hline$>40$ & $108(28.3)$ & $9(39.1)$ & \\
\hline \multicolumn{4}{|l|}{ All prescribed drugs } \\
\hline 1 & $47(12.3)$ & $1(4.3)$ & \multirow[t]{3}{*}{0.48} \\
\hline $2-3$ & $240(62.8)$ & $15(65.2)$ & \\
\hline$>3$ & $95(24.9)$ & $7(30.4)$ & \\
\hline \multicolumn{4}{|l|}{ QT prolonging drugs } \\
\hline 1 & $216(56.5)$ & $10(43.5)$ & \multirow[t]{2}{*}{0.22} \\
\hline$\geq 2$ & $166(43.5)$ & $13(56.5)$ & \\
\hline QT drug-drug interactions & $109(28.5)$ & $9(39.9)$ & 0.27 \\
\hline \multicolumn{4}{|l|}{ Diagnosis } \\
\hline Psychosis & $29(7.6)$ & $2(8.7)$ & 0.84 \\
\hline Manic depressive psychosis & $33(8.6)$ & $10(13)$ & 0.47 \\
\hline Obsessive compulsive disorder & $16(4.2)$ & $2(8.7)$ & 0.30 \\
\hline Schizophrenia & $16(4.2)$ & $1(4.3)$ & 0.97 \\
\hline Major depression & $200(52.4)$ & $11(47.8)$ & 0.67 \\
\hline Hypomania & $13(3.4)$ & $0(0)$ & 0.36 \\
\hline Panic disorder & $34(8.9)$ & $0(0)$ & 0.13 \\
\hline Bipolar affective disorder & $11(2.9)$ & $0(0)$ & 0.40 \\
\hline Substance abuse & $17(4.9)$ & $0(0)$ & 0.30 \\
\hline \multicolumn{4}{|l|}{ Co-morbid illnesses } \\
\hline Hypertension & $40(10.5)$ & $3(13)$ & 0.67 \\
\hline Diabetes mellitus & $17(4.5)$ & $0(0)$ & 0.80 \\
\hline Epilepsy & $13(3.4)$ & $0(0)$ & 0.27 \\
\hline \multicolumn{4}{|c|}{ QT prolonging drug classes (ATC Code) } \\
\hline Antipsychotic (N05A) & $140(36.6)$ & $11(47.8)$ & 0.28 \\
\hline Proton pump inhibitors (A02BC) & $48(12.6)$ & $1(4.3)$ & 0.24 \\
\hline Antidepressant (N06A) & $253(66.2)$ & $14(60.9)$ & 0.59 \\
\hline Other drugs & $19(5)$ & $2(8.7)$ & 0.43 \\
\hline
\end{tabular}

a Percentage calculated in total of 382 patients with normal QTc interval except gender; ${ }^{\mathrm{b}}$ Percentage calculated in total of 23 patients with prolonged QTc interval except gender

morbid illnesses, which are not in agreement with other studies $[8,27]$. This variation in results may be due to small sample size, and lower mean age of study participants ( 34.6 years).
Table 3 Frequency of QT prolonging drugs and their therapeutic classes along with TdP risk categories among patients with prolonged OTc interval

\begin{tabular}{|c|c|c|c|}
\hline Therapeutic class & $\mathrm{TdP}$ risk ${ }^{\mathrm{a}}$ & $\begin{array}{l}\text { QT prolonging } \\
\text { drugs (ATC Code) }\end{array}$ & n $(\%)$ \\
\hline \multirow[t]{7}{*}{$\begin{array}{l}\text { Antidepressants } \\
(n=13)\end{array}$} & $\begin{array}{l}\text { Known } \\
(n=4)\end{array}$ & Escitalopram (N06AB10) & $\begin{array}{l}4 \\
(17.4)\end{array}$ \\
\hline & \multirow[t]{2}{*}{ Possible (2) } & Clomipramine (N06AA04) & $\begin{array}{l}1 \\
(4.3)\end{array}$ \\
\hline & & Venlafaxine (N06AX16) & $\begin{array}{l}1 \\
(4.3)\end{array}$ \\
\hline & \multirow{4}{*}{$\begin{array}{l}\text { Conditional } \\
\text { (7) }\end{array}$} & Sertraline (N06AB06) & $3(13)$ \\
\hline & & Fluoxetine (N06CA03) & $\begin{array}{l}2 \\
(8.7)\end{array}$ \\
\hline & & Fluvoxamine (N06AB08) & $\begin{array}{l}1 \\
(4.3)\end{array}$ \\
\hline & & Paroxetine (N06AB05) & $\begin{array}{l}1 \\
(4.3)\end{array}$ \\
\hline \multirow[t]{5}{*}{ Antipsychotics (5) } & \multirow[t]{2}{*}{ Known (2) } & Haloperidol (N05AD01) & $\begin{array}{l}1 \\
(4.3)\end{array}$ \\
\hline & & Levosulpiride (N05AL07) & $\begin{array}{l}1 \\
(4.3)\end{array}$ \\
\hline & \multirow[t]{2}{*}{ Possible (2) } & Risperidone (N05AX08) & $\begin{array}{l}1 \\
(4.3)\end{array}$ \\
\hline & & Aripiprazole (N05AX12) & $\begin{array}{l}1 \\
(4.3)\end{array}$ \\
\hline & $\begin{array}{l}\text { Conditional } \\
\text { (1) }\end{array}$ & Olanzapine (N05AH03) & $\begin{array}{l}1 \\
(4.3)\end{array}$ \\
\hline $\begin{array}{l}\text { Proton pump } \\
\text { inhibitors (2) }\end{array}$ & $\begin{array}{l}\text { Conditional } \\
\text { (2) }\end{array}$ & Esomeprazole (A02BC05) & $\begin{array}{l}2 \\
(8.7)\end{array}$ \\
\hline \multirow[t]{2}{*}{ Diuretics (2) } & \multirow[t]{2}{*}{$\begin{array}{l}\text { Conditional } \\
\text { (2) }\end{array}$} & $\begin{array}{l}\text { Hydrochlorothiazide } \\
\text { (CO3AA03) }\end{array}$ & $\begin{array}{l}1 \\
(4.3)\end{array}$ \\
\hline & & Furosemide (C03CA01) & $\begin{array}{l}1 \\
(4.3)\end{array}$ \\
\hline Antinausea (1) & Known (1) & Domperidone (A03FA03) & $\begin{array}{l}1 \\
(0.9)\end{array}$ \\
\hline
\end{tabular}

A high proportion of patients were exposed to QT prolonging risk factors, of which QT prolonging drugs were most common, followed by female gender and hypertension. Almost $92 \%$ of patients were exposed to QT prolonging drugs, of which, considerable number of patients were taking multiple QT prolonging drugs concomitantly. While, literature suggests avoiding concomitant use of antidepressants and antipsychotics, when possible, but it is usually impossible in psychiatric population [27]. Therefore, proper risk assessment and vigilant monitoring is recommended to identify patients at low/high risk of QTIP. Risk assessment tools as developed by Vandael et al. [48] should be integrated in routine practice in psychiatry wards in order to develop a risk score on the basis of which patients will be either included or excluded for further follow up. 
Table 4 Logistic regression analysis

\begin{tabular}{|c|c|c|c|c|}
\hline \multirow[t]{2}{*}{ Variables } & \multicolumn{2}{|c|}{ Univariate analysis } & \multicolumn{2}{|c|}{ Multivariate analysis } \\
\hline & OR $(95 \% \mathrm{Cl})$ & $p$-value & OR $(95 \% \mathrm{Cl})$ & $p$-value \\
\hline \multicolumn{5}{|l|}{ Gender } \\
\hline Female & Reference & & Reference & \\
\hline Male & $3.2(1.1-9.5)$ & 0.03 & $5.6(1.6-19.8)$ & 0.007 \\
\hline \multicolumn{5}{|l|}{ Age (years) } \\
\hline$\leq 20$ & $2.1(0.5-7.7)$ & 0.26 & $2.8(0.6-11.3)$ & 0.15 \\
\hline $21-30$ & Reference & & Reference & \\
\hline $31-40$ & $1.1(0.2-4.5)$ & 0.87 & $1.3(0.2-5.9)$ & 0.71 \\
\hline$>40$ & $2.1(0.6-7.3)$ & 0.20 & $2.5(0.6-9.1)$ & 0.16 \\
\hline \multicolumn{5}{|l|}{ All prescribed drugs } \\
\hline 1 & Reference & & Reference & \\
\hline $2-3$ & $2.9(0.3-22.7)$ & 0.32 & $5.5(0.5-57.2)$ & 0.14 \\
\hline$>3$ & $3.5(0.4-28.9)$ & 0.25 & $8.5(0.6-111.3)$ & 0.10 \\
\hline \multicolumn{5}{|l|}{ QT prolonging Drugs } \\
\hline 1 & Reference & & Reference & \\
\hline$\geq 2$ & $1.7(0.7-3.9)$ & 0.22 & $1.9(0.6-5.1)$ & 0.23 \\
\hline \multicolumn{5}{|l|}{ Medical illnesses } \\
\hline Psychosis & $1.2(0.2-5.1)$ & 0.84 & $5.7(0.7-41.8)$ & 0.08 \\
\hline Obsessive compulsive disorder & $2.1(0.4-10.1)$ & 0.32 & $2.3(0.2-19.9)$ & 0.45 \\
\hline Schizophrenia & $1.04(0.1-8.2)$ & 0.97 & $8.2(0.7-95.1)$ & 0.09 \\
\hline Major depression & $0.8(0.3-1.9)$ & 0.67 & $3.8(0.7-20.4)$ & 0.11 \\
\hline Manic depressive psychosis & $1.6(0.4-5.6)$ & 0.47 & $2.3(0.3-13.6)$ & 0.35 \\
\hline \multicolumn{5}{|l|}{ Co-morbid illnesses } \\
\hline Hypertension & $1.3(0.3-4.5)$ & 0.69 & $0.5(0.1-2.9)$ & 0.50 \\
\hline Antipsychotics & $1.6(0.6-3.6)$ & 0.28 & $1.9(0.4-9.3)$ & 0.38 \\
\hline Proton pump inhibitors & $0.3(0.04-2.4)$ & 0.26 & $6.6(0.7-62.5)$ & 0.09 \\
\hline Other drugs & $1.8(0.3-8.3)$ & 0.44 & $0.6(0.1-3.9)$ & 0.59 \\
\hline
\end{tabular}

Although, the present study highlighted an important area of patients' safety, but there are some limitations which need to be addressed in future studies. Following are the potential limitations of this study such as this study was conducted in a single city which may limit the generalizability of the findings. Therefore, a multicenter study in future may provide a better insight regarding this issue. We did not assess the association of QTIP with duration of illness, and the duration of use of antipsychotics and antidepressants. Moreover, in our study the sample size for major depression was high compared to other psychiatric disorders which may lead to potential bias, therefore, inclusion of patients with equal frequency of other psychiatric disorders may address this issue. Further, we used CredibleMeds ${ }^{\circ}$ list of QT prolonging drugs as a reference in order to identify prescribed QT prolonging drugs. This database has its own criteria for the inclusion of QT drugs, hence some drugs other than the enlisted ones might be having QT prolonging effect.

\section{Conclusions}

The present study identified QTIP in considerable number of patients. A high proportion of psychiatric patients were exposed to QT prolonging risk factors, of which, QT prolonging drugs were most common. Therefore, proper consideration should be offered to the assessment of QTIP and selection of drug therapy in these patients (male patients in particular) in the presence of QT prolonging risk factors in order to ensure patients' safety and prevent life-threatening cardiac arrhythmias.

\section{Supplementary information}

Supplementary information accompanies this paper at https://doi.org/10. 1186/s12888-020-02687-w.

Additional file 1: Table S1. Comparative analysis of patients with normal and prolonged QTc interval using Bazett's correction formula.

Additional file 2: Table S2. Cases with high probability of drug induced QT interval prolongation. 


\section{Abbreviations}

IRB: Institutional Review Board;; QTc: Corrected QT interval; QT-DDIs: QT drugdrug interactions; QTIP: QT interval prolongation; TdP: Torsade de pointes

\section{Acknowledgments \\ None}

\section{Authors' contributions}

All authors contributed to the study design, data acquisition, data analysis and interpretation. Z.A. participated in the data collection, study design, data analysis and interpretation, and drafting the manuscript. M.l. participated in the data analysis, study design and data interpretation, drafting and revision of the manuscript. Z.N. participated in data interpretation and the revision of manuscript. F.K. and Q.K. reviewed the manuscript and participated in data analysis and provided guidance on interpreting the results. S.N. reviewed drafts of the paper. All authors have approved the final version of the manuscript.

\section{Funding}

This research did not receive any specific grant from funding agencies in the public, commercial, or not-for-profit sectors.

\section{Availability of data and materials}

The datasets used and/or analyzed during the current study are available from the corresponding author on reasonable request.

\section{Ethics approval and consent to participate}

Ethical approval was obtained from the Institutional Review Board (IRB) of Medical Teaching Institute (MTI), Lady Reading Hospital (LRH), Peshawar, Khyber Pakhtunkhwa, Pakistan vide reference number 09/1RB. Before participation written consent was taken from each participant.

\section{Consent for publication}

Not applicable.

\section{Competing interests}

None of the authors have any competing interests.

\section{Author details}

${ }^{1}$ Department of Pharmacy, University of Peshawar, Peshawar, Khyber Pakhtunkhwa, Pakistan. ${ }^{2}$ Department of Psychiatry, Lady Reading Hospital, Peshawar, Khyber Pakhtunkhwa, Pakistan. ${ }^{3}$ Department of Pharmacy, COMSATS University Islamabad, Abbottabad Campus, Abbottabad, Khyber Pakhtunkhwa, Pakistan.

Received: 5 July 2019 Accepted: 20 May 2020

Published online: 03 June 2020

\section{References}

1. Hondeghem LM, Drug-Induced QT. Prolongation and Torsades de pointes: an all-exclusive relationship or time for an amicable separation? Drug Saf. 2018;41(1):11-7. https://doi.org/10.1007/s40264-017-0584-4.

2. Kallergis EM, Goudis CA, Simantirakis EN, Kochiadakis GE, Vardas PE. Mechanisms, risk factors, and management of acquired long QT syndrome: a comprehensive review. Sci World J. 2012;2012:212178. https://doi.org/10. 1100/2012/212178.

3. Bhuiyan TA, Graff C, Kanters JK, Nielsen J, Melgaard J, Matz J, et al. The Tpeak-T-end interval as a marker of repolarization abnormality: a comparison with the QT interval for five different drugs. Clin Drug Investig. 2015;35(11): 717-24. https://doi.org/10.1007/s40261-015-0328-0.

4. Vandael E, Marynissen T, Reyntens J, Spriet I, Vandenberghe J, Willems R, et al. Frequency of use of QT-interval prolonging drugs in psychiatry in Belgium. Int J Clin Pharm. 2014;36(4):757-65. https://doi.org/10.1007/s11096014-9953-6.

5. Roden DM, Viswanathan PC. Genetics of acquired long QT syndrome. J Clin Invest. 2005;115(8):2025-32. https://doi.org/10.1172/JCl25539.

6. van Noord C, Eijgelsheim M, Stricker BH. Drug- and non-drug-associated QT interval prolongation. Br J Clin Pharmacol. 2010;70(1):16-23. https://doi.org/ 10.1111/j.1365-2125.2010.03660.x.
7. Woosley R.L., Heise C.W., Gallo T., Tate J., Woosley D., K.A. Romero. CredibleMeds Database. 2018. https://www.crediblemeds.org/. Accessed 25 Sept 2018.

8. Heemskerk CPM, Pereboom M, van Stralen K, Berger FA, van den Bemt P, Kuijper AFM, et al. Risk factors for QTc interval prolongation. Eur J Clin Pharmacol. 2018;74(2):183-91. https://doi.org/10.1007/s00228-017-2381-5.

9. Nose M, Bighelli I, Castellazzi M, Martinotti G, Carra G, Lucii C, et al. Prevalence and correlates of QTc prolongation in Italian psychiatric care: cross-sectional multicentre study. Epidemiol Psychiatr Sci. 2016;25(6):532-40. https://doi.org/10.1017/S2045796015000906.

10. Zemrak WR, Kenna GA. Association of antipsychotic and antidepressant drugs with Q-T interval prolongation. Am J Health Syst Pharm. 2008;65(11): 1029-38. https://doi.org/10.2146/ajhp070279.

11. Mojtabai R, Olfson M. National trends in psychotropic medication polypharmacy in office-based psychiatry. Arch Gen Psychiatry. 2010;67(1): 26-36. https://doi.org/10.1001/archgenpsychiatry.2009.175.

12. Moller HJ, Seemuller F, Schennach-Wolff R, Stubner S, Ruther E, Grohmann R. History, background, concepts and current use of comedication and polypharmacy in psychiatry. Int J Neuropsychopharmacol. 2014;17(7):98396. https://doi.org/10.1017/S1461145713000837.

13. Khan Q, Ismail M, Haider I, Khan F. Prevalence of QT interval prolonging drug-drug interactions (QT-DDIs) in psychiatry wards of tertiary care hospitals in Pakistan: a multicenter cross-sectional study. Int J Clin Pharm. 2017;39(6):1256-64. https://doi.org/10.1007/s11096-017-0532-5.

14. Kukreja S, Kalra G, Shah N, Shrivastava A. Polypharmacy in psychiatry: a review. Mens Sana Monogr. 2013;11(1):82-99. https://doi.org/10.4103/09731229.104497.

15. Comer JS, Olfson M, Mojtabai R. National trends in child and adolescent psychotropic polypharmacy in office-based practice, 1996-2007. J Am Acad Child Adolesc Psychiatry. 2010;49(10):1001-10. https://doi.org/10.1016/j.jaac. 2010.07.007

16. Preskorn SH, Flockhart D. Blog archives 2006 guide to psychiatric Drug interactions. Primary Psychiatry. 2006;13(4):35-64.

17. Möller H-J, Seemüller F, Schennach-Wolff R, Stübner S, Rüther E, Grohmann R. History, background, concepts and current use of comedication and polypharmacy in psychiatry. Int J Neuropsychopharmacol. 2014;17(7):983-96.

18. Ghaemi SN, editor. Polypharmacy in psychiatry. Marcel Dekker, Inc., New York; 2002:101-32.

19. PRESKORN SH, LACEY RL. Polypharmacy: when is it rational? J Psychiatr Pract. 2007;13(2):97-105.

20. Trivedi MH, Fava M, Wisniewski SR, Thase ME, Quitkin F, Warden D, et al. Medication augmentation after the failure of SSRIs for depression. N Engl J Med. 2006;354(12):1243-52. https://doi.org/10.1056/NEJMoa052964.

21. Association AP. Practice guideline for the treatment of patients with bipolar disorder (revision). American Psychiatric Pub; 2002.

22. Association AP. Practice guideline for the treatment of patients with eating disorders (revision). Am J Psychiatry. 2000;157(1):1.

23. Wijkstra J, Lijmer J, Balk FJ, Geddes JR, Nolen WA. Pharmacological treatment for psychotic depression: Cochrane systematic review and metaanalysis. Eur Neuropsychopharmacol. 2005;15:S393.

24. Chastang A, Renet S, Corny J, Beaussier H, Petre A, Lillo-Lelouet A, et al. Impact of hospital pharmacist interventions on the combination of citalopram or escitalopram with other QT-prolonging drugs. Int J Clin Pharm. 2019;41(1):42-8. https://doi.org/10.1007/s11096-018-0724-7.

25. Coughtrie AL, Behr ER, Layton D, Marshall V, Camm AJ, Shakir SAW. Drugs and life-threatening ventricular arrhythmia risk: results from the DARE study cohort. BMJ Open. 2017;7(10):e016627. https://doi.org/10.1136/bmjopen-2017-016627.

26. Viola R, Csukonyi K, Doro P, Janka Z, Soos G. Reasons for polypharmacy among psychiatric patients. Pharm World Sci. 2004;26(3):143-7. https://doi.org/10.1023/B:PHAR.0000026800.13888.b0.

27. Rodriguez-Leal CM, Lopez-Lunar E, Carrascosa-Bernaldez JM, ProvencioArranz RM. Electrocardiographic surveillance in a psychiatric institution: avoiding iatrogenic cardiovascular death. Int J Psychiatry Clin Pract. 2017; 21(1):64-6. https://doi.org/10.1080/13651501.2016.1234623.

28. Berling I, Gupta R, Bjorksten C, Prior F, Whyte IM, Berry S. A review of ECG and QT interval measurement use in a public psychiatric inpatient setting. Australas Psychiatry. 2018;26(1):50-5. https://doi.org/10.1177/ 1039856217726212

29. Beach SR, Celano CM, Noseworthy PA, Januzzi JL, Huffman JC. QTC prolongation, torsades de pointes, and psychotropic medications. Psychosomatics. 2013;54(1):1-13. https://doi.org/10.1016/j.psym.2012.11.001. 
30. Fridericia LS. Die Systolendauer im Elektrokardiogramm bei normalen Menschen und bei Herzkranken. Acta Medica Scandinavica. 1920;53(1):469-86.

31. Bazett HC. An analysis of the time relations of electrocardiograms. Heart. 1920:7:353-70.

32. Goldenberg I, Moss AJ, Zareba W. QT interval: how to measure it and what is "normal". J Cardiovasc Electrophysiol. 2006;17(3):333-6. https://doi.org/10. 1111/j.1540-8167.2006.00408.x.

33. Roden DM. Drug-induced prolongation of the QT interval. N Engl J Med. 2004;350(10):1013-22. https://doi.org/10.1056/NEJMra032426.

34. Micromedex-DrugReax ${ }^{\oplus}$. Micromedex Drug-Reax ${ }^{\bullet}$. Greenwood Village: Truven Health Analytics; 2018. https://www.micromedexsolutions.com/ home/dispatch/ssl/true. Accessed 8 Sept 2018.

35. Warner JP, Barnes TR, Henry JA. Electrocardiographic changes in patients receiving neuroleptic medication. Acta Psychiatr Scand. 1996;93(4):311-3. https://doi.org/10.1111/j.1600-0447.1996.tb10653.x.

36. Mackin $\mathrm{P}$, Young AH. QTC interval measurement and metabolic parameters in psychiatric patients taking typical or atypical antipsychotic drugs: a preliminary study. J Clin Psychiatry. 2005;66(11):1386-91.

37. Girgis S, Huckstep B, Oakley J, Ferriter M, Nikolaou V. QTc-interval abnormalities in a forensic population. Crim Behav Ment Health. 2007;17(2): 75-88. https://doi.org/10.1002/cbm.630.

38. Ozeki Y, Aoki T, Fujii K, Kurimoto N, Takahashi J, Ishida N, et al. Risk factors of QT interval prolongation in Japanese patients with schizophrenia. Int J Neuropsychopharmacol. 2008;1 1:149.

39. Girardin FR, Gex-Fabry M, Berney P, Shah D, Gaspoz JM, Dayer P. Druginduced long QT in adult psychiatric inpatients: the 5-year cross-sectional ECG screening outcome in psychiatry study. Am J Psychiatry. 2013;170(12): 1468-76. https://doi.org/10.1176/appi.ajp.2013.12060860.

40. Poncet A, Gencer B, Blondon M, Gex-Fabry M, Combescure C, Shah D, et al. Electrocardiographic screening for prolonged QT interval to reduce sudden cardiac death in psychiatric patients: a cost-effectiveness analysis. PLoS One. 2015;10(6):e0127213. https://doi.org/10.1371/journal.pone.0127213.

41. Miura N, Saito T, Taira T, Umebachi R, Inokuchi S. Risk factors for QT prolongation associated with acute psychotropic drug overdose. Am J Emerg Med. 2015;33(2):142-9. https://doi.org/10.1016/j.ajem.2014.09.048.

42. Sadanaga T, Sadanaga F, Yao H, Fujishima M. Abnormal QT prolongation and psychotropic drug therapy in psychiatric patients: significance of bradycardia-dependent QT prolongation. J Electrocardiol. 2004;37(4):267-73. https://doi.org/10.1016/j.jelectrocard.2004.07.001.

43. Ramos-Rios R, Arrojo-Romero M, Paz-Silva E, Carballal-Calvo F, BouzonBarreiro JL, Seoane-Prado J, et al. QTc interval in a sample of long-term schizophrenia inpatients. Schizophr Res. 2010;116(1):35-43. https://doi.org/ 10.1016/j.schres.2009.09.041.

44. Yang FD, Wang XQ, Liu XP, Zhao KX, Fu WH, Hao XR, et al. Sex difference in QTc prolongation in chronic institutionalized patients with schizophrenia on longterm treatment with typical and atypical antipsychotics. Psychopharmacology. 2011;216(1):9-16. https:/doi.org/10.1007/s00213-011-2188-5.

45. Rabkin SW. Impact of age and sex on QT prolongation in patients receiving Psychotropics. Can J Psychiatr. 2015;60(5):206-14. https://doi.org/10.1177/ 070674371506000502.

46. Reilly JG, Ayis SA, Ferrier IN, Jones SJ, Thomas SH. QTC-interval abnormalities and psychotropic drug therapy in psychiatric patients. Lancet. 2000; 355(9209):1048-52. https://doi.org/10.1016/50140-6736(00)02035-3.

47. Ozeki Y, Fujii K, Kurimoto N, Yamada N, Okawa M, Aoki T, et al. QTc prolongation and antipsychotic medications in a sample of 1017 patients with schizophrenia. Prog Neuro-Psychopharmacol Biol Psychiatry. 2010;34(2): 401-5. https://doi.org/10.1016/j.pnpbp.2010.01.008.

48. Vandael E, Vandenberk B, Vandenberghe J, Spriet I, Willems R, Foulon V. Development of a risk score for QTc-prolongation: the RISQ-PATH study. Int J Clin Pharm. 2017;39(2):424-32. https://doi.org/10.1007/s1 1096-017-0446-2.

\section{Publisher's Note}

Springer Nature remains neutral with regard to jurisdictional claims in published maps and institutional affiliations.

Ready to submit your research? Choose BMC and benefit from:

- fast, convenient online submission

- thorough peer review by experienced researchers in your field

- rapid publication on acceptance

- support for research data, including large and complex data types

- gold Open Access which fosters wider collaboration and increased citations

- maximum visibility for your research: over $100 \mathrm{M}$ website views per year

At BMC, research is always in progress.

Learn more biomedcentral.com/submissions 